\title{
Does managerial ability matter for the choice of seasoned equity offerings?
}

\begin{abstract}
We provide evidence that managerial ability is positively and significantly related to the issuance method decision of seasoned equity offerings (SEOs) in the U.S. market. Our result is robust after controlling for various internal and external governance mechanisms, addressing the problem of endogeneity, and adopting a number of alternative specifications. We further find that the impact of managerial ability on the SEOs issuance choice is stronger for firms with higher information asymmetry, CEO duality and weaker governance settings. Overall, our study supports the notion that higher managerial ability is perceived as a positive quality certification on firm information environments.
\end{abstract}

Keywords: Seasoned equity offerings; Managerial ability; Information asymmetry; CEO duality; Institutional investors

JEL Classification: G13, G32, M42 


\section{Introduction}

Extant research on seasoned equity offerings links issuance method choice with information asymmetry, information content, signalling, market timing, moral hazard and elasticity of stock demand (e.g., Heron and Lie, 2004; Cronqvist and Nilsson, 2005; Gao and Ritter, 2010; Pandes, 2010; Autore et al., 2011). Chemmanur and Paeglis (2005) posit that better and more reputable managers can convey the intrinsic value of their firm more credibly to outsiders, thereby reducing firm-level information asymmetry in the equity market. Chemmanur et al. (2010) observe that firm SEO performance is positively related with managerial quality. We posit that managerial quality should also be an important aspect of the prior SEO issue execution process. To date, however, the current literature is silent on the potentially important association between top management characteristics and SEO issuance preferences. Extending existing research, we focus on the role of managerial quality and argue that the quality and reputation of a firm's management will feed into the quality assurance and information set associated with SEO issues and are expected to influence firm issuance choice decision-making in SEOs.

The current literature has also highlighted the important role of managerial ability in improving firm quality (e.g., Beasley, 1996; Demerjian et al., 2012, 2013). Specifically, the above studies find that higher firm managerial ability is positively related to corporate financial reporting quality, and associated with a positive managerial fixed effect on firm performance. In a similar vein, Chemmanur and Paeglis (2005) find a positive relation between managerial quality and firm performance in the post initial public offering (IPO) period. In the context of SEOs, the role of managerial ability is relatively intuitive. This is because, in an equity issuance process, the underwriters will assess firm quality when choosing to underwrite SEOs. An underwriter's risk of damaging their reputation will be lower when underwriting the SEO of a firm with a superior information environment and 
more-reputable management. This argument implies that firms with higher management quality and reputation are more likely to be associated with more reputable underwriters, which increases the success likelihood of the SEOs. Chemmanur and Paeglis (2005) further investigate the relation between firm management quality and various IPO issue aspects, including size, underwriting expenses, post announcement performance of IPOs, and indicate that management quality affects the characteristics of firm IPOs. The authors interpret their results as evidence that better and more-reputable management is more able to certify the quality of their firm to the financial markets and can reduce information asymmetry between a firm's insiders and outsiders. This argument also implies that financial intermediaries, such as underwriters, investigative accountants and institutional investors, will incur lower costs of producing information about the firm that, in turn, affects the characteristics of such firms' equity offerings, for instance, offer size, offer execution time, underwriting spread, and other offering-related expenses. Moreover, better and more-reputable managers may be able to select more suitable projects for their firms that are characterized by larger net present values for any given scale. As such, firms with higher quality managers are likely to have a greater equilibrium scale of investment and larger equity offerings (Chemmanur and Paeglis, 2005).

Regarding SEOs, accelerated offerings typically take 1 day to complete compared to 31 days between filing and offer dates in the case of fully-marketed offerings. Given this very short time-frame, the key issue is how offering firms deal with asymmetric information while using the accelerated offering method for issuing SEOs. Since an underwriter's reputation risk associated with failing to correctly assess the prospect of SEOs is heightened in the case of accelerated SEOs, the question is whether the managerial ability of the issuing firm can act as a quality certification signal for the underwriters to assess the firm's information environment. From the underwriter's point of view, compared to accelerated SEOs, in firm commitment SEOs there is time to conduct an accurate due diligence analysis. There is also a 
huge amount of information gathering and marketing effort required by underwriters as part of executing firm commitment SEOs. We argue that firms can use certification mechanisms such as the signals and indicators of managerial quality to mitigate the degree of due diligence investigation required to be completed by underwriters. We further argue that firms may employ quality management mechanisms, including people and processes, to reduce the extent of information asymmetry between managers of offering firms and potential investors, with underwriters and investment bankers mediating between them. We, therefore, posit that firms with more capable managers are more likely to select the accelerated offering process compared to the firm commitment method when undertaking SEOs.

In this paper, we investigate the certification role played by top management in SEO transactions in the U.S. equity market, and how management quality is related to firm SEO issuance method decisions. Specifically, we examine whether firms with higher management ability / quality are more likely to conduct accelerated SEOs than firm commitment offerings due to lower levels of perceived firm risk and information asymmetry. We also conduct additional analysis controlling for a number of firm-level corporate governance mechanisms to examine whether corporate governance may have a complimentary or offsetting role on how managerial quality is associated with firm outcomes. To test our hypotheses, we use the Thomson One Banker (SDC module) database to identify U.S public companies that raise equity via accelerated and firm commitment methods, and construct a U.S sample over the 2001-2013 period. We follow prior studies and create a dummy variable taking the value of one if the firm undertakes an accelerated SEO, and otherwise zero for firm commitment SEOs. In terms of top management quality, we use the managerial ability score developed by Demerjian et al. (2012) to proxy for firm-level managerial ability. To avoid omitted correlated variables, we control for a number of factors that potentially affect SEO decisions, 
as found in the current literature, and include industry- and year-fixed effects across all specifications.

The results obtained support our underlying hypothesis. We find that firms with higher quality managers (firms with higher managerial ability scores) are more likely to undertake accelerated offerings. Furthermore, this result is only found to be evident in firms with higher levels of underlying information asymmetry, supporting our assertion that managerial quality aids in resolving firm-level information asymmetry, at least as it relates to capital raising activities. Our findings further remain unchanged after controlling for potential endogeneity between managerial ability and issuance choice dynamics using propensity score matching, instrumental variable and fixed effects estimation techniques. This result still holds after controlling for the potential moderating role of various internal and external governance mechanisms.

Overall, our study contributes to the literature on the influence of managerial ability on firm-level decision-making and performance and valuation outcomes. This is the first study to examine the contribution of managerial ability to firm equity issuance decisions based on different offering characteristics associated with SEOs, and it provides further evidence on the effect of information asymmetry in motivating corporate financial decision-making. Our study adds to the limited literature that shows that managerial quality plays an important assurance role regarding the integrity of financial statements and other firm fundamental and performance information, and in reducing information asymmetry. Our findings on the relation between managerial ability and SEO offering method choice contribute to the growing literature on the positive impact of higher managerial ability (e.g., Chemmanur and Paeglis, 2005; Chemmanur et al., 2010; Demerjian et al., 2012, 2013).

The rest of the paper is organized as follows. Section 2 presents prior empirical evidence, related hypotheses, along with the objectives of this paper. A description of the data is 
provided in Section 3. Section 4 reports the empirical results and additional robustness tests, and Section 5 concludes the paper.

\section{Hypothesis development}

This study investigates the role played by skilled managers in improving firms' information environments. In a generic sense, more talented managers have more knowledge about their business and consequently make good and sensible business decisions. More capable managers are better informed about their firm and the industry they operate in, and can see how decisions and choices affect the overall long-term value of their company. Furthermore, they are better adept at selecting worthwhile projects for their firms to create higher net present value. Consistent with the existing literature, a number of prior studies provide evidence on the effect of management characteristics and styles on firm performance (e.g., Bertrand and Schoar, 2003; Fee and Hadlock, 2003; Malmendier and Tate, 2005; Switzer and Bourdon, 2011). Particularly, Demerjian et al. (2012) report that superior managers understand the role played by technology and industry trends, better manage the efficiency of day-to-day operations and generation of revenue from available resources, and utilize the proceeds from equity financing more effectively. They can reliably predict product demand, and invest in higher value projects and manage their employees more efficiently than less able managers. Milbourn (2003) also documents that good managers have higher pay-forperformance sensitivities longer CEO tenure, more prior media mentions, and are more likely to have been appointed from outside of the firm. In a similar vein, Leverty and Grace (2012) document that more skilled managers are less likely to enter into the dangers of potential bankruptcy.

Regarding the financial market reaction to actions and outcomes of higher-quality managers, Chemmanur (1993) finds that better and more reputable management teams can 
convey the value of their firms more credibly to the equity market and, thus, reduce information asymmetry. Moreover, firms with reputable management exhibit lower underpricing levels in equity offerings. Similarly, Chemmanur and Paeglis (2005) examine the relation between managerial ability and reputation and a variety of firm IPO characteristics and post-IPO performance. They provide evidence of a positive relation between managerial quality and offer volume, offer characteristics and long-term performance. Chemmanur et al. (2009) support that firms with less information asymmetry are more likely to favor issuance of equity, and receive a fair price for it. Chemmanur et al. (2010) identify better firm performance from completing SEOs in the presence of superior management practices. They also highlight that, although in the SEO phase, the extent of the asymmetric information problem is expected to be smaller than in the IPO phase, as SEOs are typically conducted by mature and more complex firms and, hence, the influence of management quality on firm value is expected to be higher in SEOs than in the IPO context. Although existing empirical findings support the contention that firms conducting SEOs face less information asymmetry compared to that observed for IPOs, one might expect that a higher level of management quality coupled with less information asymmetry may result in different SEO issuance method choice. Prior studies have ignored such a possibility.

On the other hand, the existing literature documents that larger and more valuable firms are more likely to choose accelerated SEOs to raise additional equity capital (Bortolotti et al., 2008). The accelerated SEOs process is completed in 1 day, as compared to 31 days for fully marketed or firm commitment offerings. Accelerated offerings increase competition between underwriters and place additional pressures on them to do their due diligence investigations more thoroughly, due to the restricted time process (Koerniadi and Tourani-Rad, 2015). This time constraint could potentially increase the cost of investigations and, hence, the signaling role of leadership skills becomes increasingly crucial. In this sense, we argue that firms with 
higher managerial ability can act as a quality assurance mechanism that reduces the cost of due diligence associated with the equity issue process both from demand and supply side dynamics. Moreover, SEO firms with more skilled managers may reduce the pressure on underwriters and, therefore, they can quickly assess the market demand before committing to an offer price. Further, firms with higher management quality have been found to be associated with more reputable underwriters. Given the reduction in the extent and cost of due diligence activities, the time difference required to complete the two different SEO issue techniques, and the identified lower level of information asymmetry associated with firms with higher managerial ability, we therefore predict the main hypothesis as follows:

Hypothesis: There is a positive relationship between firm-level managerial ability and the likelihood of undertaking an accelerated SEO offering rather than a firm commitment offering.

\section{Sample and descriptive}

Our primary data source constitutes all the seasoned equity offerings announced during the period 2001 to 2013 by U.S public companies. We use the Thomson One Banker (SDC module) database to identify U.S public companies that raise equity via accelerated and firm commitment methods. Initially, we obtain a raw sample of 17,289 seasoned equity offerings. We then exclude 7,433 offerings because they do not have any shelf offering details in the SDC module. We further delete events with incomplete offering firm codes, duplicate issuances, and those issues which are units, preference shares, warrants, trust units, American Depositary Shares (ADRs), and convertible bonds. We also exclude firms without the managerial ability measure provided by Demerjian et al. (2012). The final sample consists of 1,568 distinct events. The details of sample exclusions are reported in Table 1.

\section{[Insert Table 1 here]}


We collect firm-level annual accounting data (at the balance sheet date immediately before the issue announcement) from the Compustat database. We also access the ThomsonReuters Institutional Holdings (13F) database to collect institutional investors' data as at the last quarter immediately before the issue announcement.

Table 2 provides a summary composition of the final sample for the study. Specifically, Panel A shows the year-by-year and offering type-based distributions, Panel B presents information on the offering type, and Panel $\mathrm{C}$ reports a categorization by industry sectors. Several features in Table 2 are worth noting. The table shows that offerings are predominantly from the manufacturing industry with 629 observations (approx. $37.84 \%$ of the sample), while the retail industry is the next most strongly represented. As can be seen in Table 2, $88.02 \%$ of sample SEO offerings are firm commitment, while $11.98 \%$ are accelerated offerings. Given that the accelerated offering method is less commonly adopted by firms, it is particularly relevant to identify attributes correlated with its usage or otherwise.

\section{[Insert Table 2 here]}

Table 3 reports basic univariate descriptive statistics for the sample. ${ }^{1}$ We report sample mean and median values of key economic variables for two subgroups: accelerated and firm commitment SEOs. The table also presents the results for the non-parametric univariate test (Mann-Whitney $[\mathrm{MW}]$ ) of the difference in median values between these two subgroups.

\section{[Insert Table 3 here]}

Several features are worthy of note from the comparison of accelerated versus firm commitment offerings. Specifically, relative to firm commitment offerings, firms with accelerated offerings have larger firm size $(S I Z E)$, market value $(M V)$, and age $(A G E)$, lower idiosyncratic risk (IDYRISK) in the year before the SEO offering announcement, higher liquidity (LIQUID) in the year before the issue announcement, lower standard deviation of

\footnotetext{
${ }^{1}$ We present definitions of all the variables in the Appendix.
} 
monthly returns $(S D V O L)$ and earnings (SDEAR), greater leverage (LEVERAGE), higher institutional ownership (INSDED, INSQUASI, INSTRA), and a greater relative size of SEOs (OPTOTA). Thus, it is larger, older, and less risky firms, and firms more attractive to institutional investors, that tend to undertake accelerated SEOs.

\section{Regression results}

\subsection{Managerial ability and the issuance choice of SEOS}

This section investigates the impact of firm-level managerial ability on the firm issuance choice for SEOs by performing probit regressions of the SEO choice dummy on the managerial ability variables, controlling for firm-level factors. The probit regression model is given as:

$$
\text { SEOchoice }_{i, t}=\alpha+\beta M A_{i, t-1}+\gamma \text { Controls }_{i, t-1}+\varepsilon_{i, t}
$$

where, SEOchoice $i, t$ is a dummy variable taking the value of one if the firm undertakes an accelerated SEO, otherwise zero for firm commitment SEOs. We employ the managerial ability score developed by Demerjian et al. (2012) to proxy for managerial ability $\left(M A_{i, t-1}\right)$. At first, Demerjian et al. (2012) use the data envelopment analysis (DEA) technique to generate firm-level efficiency scores within a particular industry, where efficient firms are those that generate more revenues from a given set of resources (e.g., Cost of Goods Sold; Selling, General \& Administrative Expense; Net Property Plant and Equipment; Net Operating Leases; Net Research and Development; Purchased Goodwill; and Other Intangible Assets). They specifically solve the optimization problem as follows: Firstly, the five variables, including Net Property Plant and Equipment; Net Operating Leases; Net Research and Development; Purchased Goodwill; and Other Intangible Assets are measured at the beginning of year $t$, while the two flow variables (Cost of Goods Sold and Selling, General \& Administrative Expense) are measured over year $t$. They estimate DEA efficiency (total firm 
efficiency) by industry group to identify efficiency levels for industries that have similar technologies and business models used to convert resources into outputs. Second, they regress the total firm efficiency score on various firm characteristics such as size, market share, cash availability, life cycle, operational complexity, and foreign operations to separate out the firm-specific efficiency factors from the total firm efficiency score. The residual, the total firm efficiency component unexplained by the firm characteristics, is attributed to managerial ability.

This study further employs a number of other firm-level control variables (Controls ( $_{i, t-1}$ ) that could potentially influence firms' SEO choices and, hence, they should be controlled for in a multivariate setting (e.g., Chemmanur and Paeglis, 2005; Chemmanur et al., 2010; Demerjian et al., 2012, 2013). All control variables are measured over, or at the end of, the previous year, including firm size (SIZE), liquidity (LIQUID), risk (IDYRISK), relative issue size (OPTOTA), shelf offering (DSHELF, DSHELF_l), age (AGE), book-to-market ratio $(B M)$, and leverage (LEVERAGE). The construction of the related variables is detailed in the Appendix.

It is also noticed that one of the potential concerns in our analysis is endogeneity. We mitigate this issue by employing the one-lagged managerial ability measure and one-lagged control variables in all regressions. Year and industry dummies are also included to control for year- and industry-specific effects, respectively. We also estimate our model by using robust standard errors to account for heteroscedasticity and firm-level clustering. Furthermore, the models across specifications are chosen after checking for multi-collinearity and model specification error. In the robustness analysis section, we also employ a number of other forms of analysis to specifically address the potential endogeneity of managerial ability.

Table 4 presents the empirical analysis results for the relation between managerial ability and SEO issuance choice using various alternative specifications. As reported in a standard 
regression (Model (1)) of Table 4, the coefficient for managerial ability (MA) is positive and statistically significant (beta coeff $=1.470$ and $p<0.01$ ). This result supports our main hypothesis that firms with higher managerial ability are more likely to undertake accelerated offerings. In terms of economic significance, firms with $M A$ in the $75^{\text {th }}$ percentile are $46 \%$ more likely to complete an accelerated SEO offering compared to those firms in the $25^{\text {th }}$ percentile (that is, $\exp (1.080 \times 0.06) /(\exp (-1.080 \times-0.13)=0.461)$, controlling for other variables.

We next conduct additional analyses on the impact of managerial ability, controlling for the full set of alternative specifications aimed at mitigating the influence of other indicated determinants of firms' SEO issuance preferences. We report the results in Models (2) through (6) of Table 4. The coefficient for the $M A$ variable is positive and statistically significant across all specifications, suggesting that firms with greater managerial ability are more likely to issue seasoned equity using the accelerated offer method. Overall, our result is consistent with the hypothesis, and supports the notion that higher managerial ability can act as a quality assurance mechanism that reduces the cost of due diligence associated with the equity issue process both from demand and supply side perspectives, and mitigates firm-level information asymmetry, and ultimately improving the information environment surrounding SEOs.

\section{[Insert Table 4 here]}

It should also be noted that the results for the other firm-level variables that are statistically significant have the anticipated signs and are in line with the current literature. For instance, firms with greater size, higher leverage, and which have shelf offerings tend to use more accelerated offerings. We further find that firms that issue accelerated offerings, on average, have lower idiosyncratic risk and higher liquidity (see Models (3) and (4), respectively), though this effect disappears when all of the control variables are evaluated together in the one model (Model (6)). Generally, we find that larger firms and firms with 
lower risk, higher leverage, greater liquidity, and higher-ability managers are more likely to undertake accelerated offerings.

Further, it is possible that the effect of managerial ability on a firm's SEO choice through reducing the degree of information asymmetry will vary for firms with different degrees of information asymmetry; for instance, this effect might be stronger for firms in industries with higher levels of information asymmetry (e.g., R\&D intensive industries). ${ }^{2}$ In line with previous studies (Chang et al., 2006; Brown and Hillegeist, 2007; Bowen et al.; 2008; Kim et al., 2016; Dang et al., 2017), we use R\&D intensive firms (R\&DINTENSIVE), number of analysts following (ANALYSTS), and the dispersion of analyst forecasts (DISP), as proxies for firm information asymmetry level. Based on prior studies, R\&D-intensive firms are defined as those operating in the chemicals and pharmaceuticals (SIC 28), machinery and computer hardware (SIC 35), electrical and electronics (SIC 36), and scientific instruments (SIC 38) sectors. We calculate analyst following as the average number of analysts making annual earnings forecasts over a 12-month period for a particular firm. We further calculate analyst forecast dispersion as the standard deviation of all earnings forecasts for the next fiscal year. We compute the analyst coverage and analyst dispersion measures using data from the Thomson Reuters I/B/E/S database.

We sort all firms in our sample into two groups for each fiscal year: a high information environment group (that is, firms with low information asymmetry) and a low information environment group (high information asymmetry) based on the median values of financial analysts following and analyst forecast dispersion for each year, and R\&D industry classification or otherwise. In the case of financial analysts, we define the high information environment group as firms having more analysts following than the median analysts following for each year of our sample (HighANALYSTS); whereas the low information

\footnotetext{
${ }^{2}$ We thank the reviewer for this suggestion.
} 
environment group is defined as firms having a lower than or equal to median level of analysts following (LowANALYSTS). Similarly, we classify firms into the high information environment category if they have a lower than median analyst forecast dispersion for each year $(L o w D I S P)$ and the low information environment category contains firms with higher than or equal to the median level of analyst forecast dispersion (HighDISP). Since we argue that managerial ability reduces firm-level information asymmetry, we posit that the relationship between managerial ability and the accelerating SEO offering method choice would be more pronounced for firms with greater information asymmetry. The results are presented in Panels A, B and C of Table 5 using each of the three proxies for information asymmetry, and including year and industry effects.

\section{[Insert Table 5 here]}

Table 5 shows that the relation between managerial ability and SEO method choice is dependent on the degree of information asymmetry inherent in firms. Overall, we find supportive evidence indicating that the degree of a particular firm's information asymmetry plays an important role in the articulation between managerial ability and equity offering decisions. We find a significant positive relation between managerial ability and the likelihood of undertaking an accelerated SEO for firms with high information asymmetry across all information asymmetry proxies (LowANALYSTS group, HighDISP group, and firms in $R \& D$ intensive industries), but no relationship between managerial ability and SEO financing method preference for firms classified as having a high information environment (low information asymmetry). This suggests that higher managerial ability moderates the effect of a weaker information environment, such as from the viewpoint of underwriters or investors, and facilitates the ability of firms to execute the quicker accelerated SEO process. For firms with less information asymmetry, these results similarly suggest that other quality and certification signaling is less important in determining SEO financing choice. 


\subsection{Endogeneity of Managerial Ability}

We conduct some additional analysis to address concerns around the potential endogeneity of managerial quality. First, we employ a propensity score matching procedure to obtain a sample of firms with a similar likelihood of employing managers with different ability. We consider high ability managers as the top quintile of managerial ability, and low ability managers as the bottom quintile of managerial ability, and examine differences between the two groups' SEO issuance decisions before and after matching. We create a control group based on propensity score matching using firm-level characteristics. Thus, the treatment and the control firms are nearly identical along all dimensions, except one, i.e. managerial ability. We then examine the relation between managerial ability and the SEO choice for this matched sample of firms. The results are reported in Table 6 and, again, support our prior findings that higher ability managers are more likely to undertake accelerated seasoned equity offerings and less likely to engage in firm commitment offerings.

\section{[Insert Table 6 here]}

Second, it is possible that the observed relation between managerial ability and the accelerated offering decision is driven by the presence of time-invariant firm-specific omitted variables, potentially leading to an under-specification bias. We mitigate this concern by performing an additional robustness check using firm fixed effects, and report the results in Table 7. The results show that the coefficient for the $M A$ variable is still positive and statistically significant across all specifications, suggesting that firm accelerated SEO issuance decisions are positively associated with firm-level managerial ability attributed.

\section{[Insert Table 7 here]}

As a further robustness test to control for potential endogeneity, we conduct instrumental variable regressions examining the relationship between managerial ability and firms' equity offering choices, controlling for any reverse causality. In the first-stage regression, we 
employ an ordinary least squares model to predict firm-level managerial ability (Panel A of Table 8). In the second-stage regression, we examine the relationship with the SEO choice variable of the managerial ability predicted (EXMA) variable from the first-stage regression and other controls used in our baseline regression (Panel B of Table 8). We employ an instrumental variable that is expected to be relate to firm-level managerial ability but should not be directly associated with firm SEO choices. Our instrumental variable is the Industrymedian MA Score (based on SIC 2 digit industry classification). Each industry includes a large number of firms and, thus, a shock to managerial ability at the industry level should be exogenous. Industry-level managerial ability is expected to be related to managerial ability at a firm-level (such as a manager taking actions to enhance their capabilities relative to industry peers, which their performance and remuneration, for instance, may be evaluated against), but there is no plausible reason why industry-wide average or median ability should be related to firm-level financing decision-making. As such, the industry-median MA score should be a suitable instrument for the purposes of this analysis. We use the predicted value (EXMA) in the second stage (Panel B of Table 8) to predict SEO issuance preferences. The first stage results in Panel A of Table 8 show that industry-median MA score is a highly statistically significant predictor of firm-level managerial ability. The second stage results in Panel B show that the sign of coefficient on the EXMA variable is consistent with those in the baseline regressions, suggesting that the positive association between firm-level managerial ability and SEO issuance decisions remains qualitatively and statistically (if anything, more highly significant) similar after controlling for endogeneity issues.

\section{[Insert Table 8 here]}

Overall, this additional analysis suggests that the significant positive relation between managerial ability and firm likelihood of undertaking accelerated offerings is robust to endogeneity concerns. These results support our hypothesis that managerial ability reduces 
information asymmetry, and firms with higher managerial ability are more likely to undertake accelerated equity offerings.

\subsection{Managerial ability, corporate governance, and SEO issuance choice}

In this section, we examine the role of managerial ability on the equity issuance preferences between accelerated versus firm commitment SEOs controlling for various corporate governance characteristics. Corporate governance is a primary mechanism for ensuring reporting transparency, reducing information asymmetry, improving stock price informativeness, and corporate governance plays a positive role in creating shareholder wealth. Koerniadi et al. (2012) find that better corporate governance strengthens the disciplinary threat of removing the management and, therefore, limits the extent to which management can expropriate firm value through shirking, empire building, overconsumption of perquisites, and risk aversion.

We examine two corporate governance attributes that are perceived to be associated with firm decision-making processes and firm-level monitoring and agency (information asymmetry) environments. These are the existence of CEO and chairperson duality (termed CEO duality) and the level and type of institution ownership present in sample firms. If these governance attributes influence the information environment and monitoring effectiveness (negatively in the case of CEO duality and positively in the case of greater institutional ownership), then through the information asymmetry channel they should have moderating roles on the managerial ability and SEO choice relationship.

It is well-accepted in the corporate governance literature that the existence of CEO duality, independent of underlying CEO ability, may create significant agency problems (Fama and Jensen, 1983). ${ }^{3}$ Fama and Jensen (1983) document that, among others, CEO

\footnotetext{
${ }^{3}$ According to Jensen and Meckling (1976) and Jensen and Ruback (1983), the agency costs which result due to the mismatch in the interests of shareholders and managers can reduce as top management ownership increases, because the personal interests of the CEOs are more inclined to converge with those of the shareholders when
} 
duality is linked to a low level of analyst coverage and, hence, a weaker firm information environment, other things being equal. They also find that CEO duality is more prominent in firms with higher R\&D expenditure, more advertising expenditure, and lower product market competition. The opacity in the firm-level information environment resulting from CEO duality is further aided since CEO replacement is more unlikely in the case of poorly performing CEOs when they hold duality positions (Goyal and Park, 2002). Moreover, CEO duality is also likely to entrench themselves against accountability (Finkelstein and D'aveni, 1994), leading to negative agency and valuation consequences resulting from entrenchment. Following this line of argument, Mallette and Hogler (1995) show that firms with independent chairman are less likely to adopt liability protection for their directors. Sundaramurthy (1996) shows that the adoption of antitakeover measures, including unequal voting rights, fair price provisions, classified board provisions, and supermajority voting requirements, among others, tends to occur in firms with CEO duality. CEO duality also compromises the monitoring effectiveness of the board. Tuggle et al. (2010) find that boards vary in their monitoring activity and that CEO duality is a strong contributor to this variance. Overall, CEO-chair duality can provide control of the board agenda and information flow so as to create norms in which questioning management effectiveness is deemed inappropriate (McNulty and Pettigrew, 1999).

Given the due diligence requirements and time constraint associated with the execution of accelerated SEOs, the control over information flow and creation of an opaque information environment when the firm's CEO also holds the position of the chairperson of the board may be an impediment to the ability of the firm to employ this offer method to raise seasoned equity. Therefore, we examine whether the positive signalling and certification effects

managerial shareholdings increase. Recently, Croci and Petmezas (2015) examine the effect of risk-taking incentives on acquisition investments and find that the bidder CEOs exposed to risk-taking incentives are more likely to conduct risky investments. 
associated with managerial ability and the related decision-making about SEO method choice persist in the presence of CEO-chair duality. We also interact the $M A$ variable with the CEODUAL variable to investigate if CEO duality status has a moderating influence on the positive relation between managerial ability and SEO issuance decisions. Accordingly, we estimate Equation (3) below, and report the regression results in Models (1) through (4) of Table 9. Our regression model is given as follows:

SEOchoice $_{i, t}=\alpha+\beta M A_{i, t-1}+\delta C E O D U A L_{i, t-1}+\vartheta M A^{*}$ CEODUAL $_{i, t-1}+\gamma$ Controls $_{i, t-1}+\varepsilon_{i, t}$

Controlling for the presence of CEO duality in the models in Table 9, we find that the $M A$ variable maintains its significant positive association with the accelerated offering likelihood indicator, albeit at the $10 \%$ level. Further, the coefficient on the CEODUAL variable is negative and statistically significant, indicating that firms with CEO duality are less (more) likely to undertake accelerated (firm commitment) SEOs. More importantly, we interact the $M A$ variable with the CEODUAL variable and document that the coefficient on the $M A * C E O D U A L$ interaction term is positive and statistically significant. This result indicates that the incremental effect of CEO duality as a negative quality certification on firms' information environment tends is less in the case of firms where the CEO has higher assessed ability. In this sense, firms with higher managerial ability, despite having the dual CEOchairman position, are more likely to choose the accelerated offering method, supporting the prediction from the main hypothesis.

\section{[Insert Table 9 here]}

In relation to institutional ownership, existing evidence indicates that institutional shareholders who hold large ownership stakes are more likely to affect corporate decisions and use their increased monitoring capacity to re-adjust the interests of shareholders and managers, leading to the reduction in information asymmetry and agency costs (Demsetz and Lehn, 1985; Shleifer and Vishny, 1986; Gillan and Starks, 2003; Hartzell and Starks, 2003; 
Tihanyi et al., 2003; Chen et al., 2007; Dalton et al., 2007; Ferreira and Matos, 2008; Ferreira et al., 2010; and Aggarwal et al., 2011).

In terms of SEOs, Gibson et al. (2004) identify an important role played by institutional investment in seasoned equity issuances. Chemmanur et al. (2009) and Burns et al. (2010) document that institutional investors have the ability to prevent value-dissipating activities within a firm, and increased institutional participation conveys positve news about the longterm prospects of the firm. More importantly, they find that firm SEOs have a lower offer price discount compared to other offerings. Hao (2014) finds that the more short-term oriented the shareholders are, the more likely an equity issuance decision will be made. However, all of the various types of institutional investors do not necessarily have the same objective function. In fact, Bushee (2001) states that the quasi-indexer and dedicated institutions provide stable long-term ownership since they are interested in long-term income and capital appreciation. Nonetheless, given that the need for increased quality certification is more important in the case of accelerated SEOs, firm-level managerial ability may be less important in the presence of external quality certification in the form of institutional investor ownership, and particularly higher levels of dedicated and active institutional ownership. Therefore, we conduct a set of tests to investigate the link between managerial ability and issuance choice of SEOs controlling for the presence of institutional investors. In order to proxy for institutional ownership, we employ a number of different institutional investor characteristics, including total institutional ownership, dedicated institutional ownership, transient institutional ownership, and active institutional ownership. Bushee (2001) contends that both dedicated and quasiindexer institutions provide stable long-term ownership and are interested in long-term income and capital appreciation. From a managerial and firm monitoring point of view, we classify institutions that fall in the quasi-indexers or dedicated groups as active institutional investors. Table 10 reports the regression results of the 
association between managerial ability and SEO issuance decisions controlling for institutional ownership (Panel A), dedicated institutional ownership (Panel B), transient institutional ownership (Panel C), and active institutional ownership (Panel D). We further combine together these institutional investor ownership types in a full model and present the results in Panel (E).

\section{[Insert Table 10 here]}

The results show that the coefficient for the $M A$ variable is positive and statistically significant at the conventional significant levels across all panels and specifications after controlling for institutional ownership. These results support the main hypothesis that firms with higher managerial ability are more likely to undertake accelerated offerings.

It is also pertinent to notice that the institutional ownership variables have no significant association with firm equity offering decisions. This is somewhat surprising given that firm equity issues have the potential to modify institutional ownership levels, subject to issue method used and institutional investor participation. It may be that institutional investor monitor or activism does not extend to the level of corporate financing decision-making, unless they take on board seats which is uncommon, or that the specific issue method chosen doesn't significantly impact on ownership or valuation outcomes for institutional investors. Alternatively, it may be that institutional investors rely on the expertise of underwriters in advising on the preferred issue method, and they may wish to avoid conflict of interest considerations in their capacity as firm shareholders.

\section{Conclusion}

This paper examines the effects of managerial ability on the issuance method choice for firm SEOs in the U.S. equity market for the period of 2001 to 2013 , and finds some new evidence. First, firms with higher managerial ability choose, or are more likely, to undertake accelerated SEOs in preference to firm commitment offerings. This result is consistent with 
the view that skilled managers can clearly convey a firm's intrinsic value to the capital market, thus reducing the information asymmetry associated with firms, and around SEO offerings, better facilitating the adoption of the accelerated SEO method. Second, firms with higher managerial ability provide a certification function for the market and offer participants, and particularly reducing the effort required for due diligence activities on the part of underwriters, vis-à-vis lowering transaction costs and execution speed for accelerated offerings. Our findings are robust to approaches that are designed to mitigate any endogeneity bias between managerial ability and SEO issuance decisions. Furthermore, we find that the positive relation between managerial ability and SEO offering choice persists after controlling for a number of corporate governance mechanisms influencing firm-level information and agency environments.

The findings in this study have important implications for investors and policy-setting bodies. Firstly, they document the direct association of managerial ability with financing decision-making tasks, and expand on the literature relating managerial ability to firm-level performance and outcomes. Furthermore, the findings suggest that managerial ability influences the actions and decisions of firm stakeholders, and particularly underwriters in the case of SEO planning and execution. Other stakeholders, such as shareholders and lenders should similarly incorporate assessment of managerial ability as a component of their information and decision-making set. This is further emphasised based on the implication that managerial ability can mitigate firm-level information asymmetry, independent of other governance or monitoring mechanisms in place at the firm-level. This latter finding should also be of interest to policy makers in terms of disclosure and compliance requirements related to equity issue processes and mandatory corporate governance code development, particularly in regards to managerial attributes, experience and expertise. 


\begin{tabular}{|c|c|c|c|}
\hline Variables & Acronym & Description & Data sources \\
\hline \multicolumn{4}{|c|}{ 1. SEO choice, Managerial ability, and CEO duality } \\
\hline SEO issuance choice & SEOchoice & $\begin{array}{l}\text { A dummy variable taking the value of one if the firm offers accelerated SEOs, otherwise zero } \\
\text { for firm commitment SEOs. }\end{array}$ & SDC \\
\hline Managerial ability & $M A$ & Firm-level managerial ability score developed by Demerjian et al. (2012). & Demerjian et al. (2012) \\
\hline \multicolumn{4}{|l|}{ 2. Other firm-level characteristics } \\
\hline Firm size & SIZE & Log of the book value of total assets. & Compustat \\
\hline Market value & $M V$ & The market value of the company one month prior to the announcement & \\
\hline Book-to-market ratio & $B M$ & Total assets/(Total assets-book value of equity + market value of equity). & Compustat \\
\hline Liquidity & LIQUID & $\begin{array}{l}\text { Logarithm of average proportionate bid-ask spread for one-year period prior to the } \\
\text { announcement of SEO offerings. }\end{array}$ & CRSP \\
\hline Idiosyncratic risk & IDYRISK & $\begin{array}{l}\text { The standard error for the } 1 \text {-year period before the announcement date (return from day }-260 \\
\text { today -2). }\end{array}$ & SDC \\
\hline Standand deviation of returns & SDVOL & Standard deviation of average monthly returns & CRSP \\
\hline Standard deviation of earnings & $S D E A R$ & Standard deviation of the EBITDA/Assets ratio over the previous 10 -year period & CRSP \\
\hline Relative issue size & OPTOTA & Offer proceeds relative to total assets. & SDC \\
\hline Shelf offerings & DSHELF & A dummy variable, which takes a value of 1 for a shelf offering, and zero otherwise & SDC \\
\hline Shelf offerings & DSHELF_l & $\begin{array}{l}\text { A dummy variable, which takes a value of } 1 \text { for offerings which satisfy shelf offering } \\
\text { requirements, and zero otherwise }\end{array}$ & SDC \\
\hline Firm age & $A G E$ & $\begin{array}{l}\text { Logarithm of age where age of the firm is measured in years since the firm entered the } \\
\text { Compustat. }\end{array}$ & Compustat \\
\hline Leverage & LEVERAGE & The ratio of total debt to total assets. & Compustat \\
\hline Independent directors & INDEP & The percentage of non-executive directors on the board. & GMI Rating \\
\hline Board size & $B S I Z E$ & Logarithm of the number of board members. & GMI Rating \\
\hline Board meetings & BMEETS & Logarithm of the number of board annual meetings. & GMI Rating \\
\hline Female directors & DGENDER & $\begin{array}{l}\text { A dummy variable which takes a value of one if at least one female director in the board and } \\
\text { zero otherwise. }\end{array}$ & GMI Rating \\
\hline CEO duality & CEODUAL & $\begin{array}{l}\text { A dummy variable taking the value of } 1 \text { if CEO is also the chairman of the board at the time } \\
\text { of the issue, and zero otherwise. }\end{array}$ & GMI Rating \\
\hline Institutional ownership & INSOWN & $\begin{array}{l}\text { Institutional ownership to share outstanding at the last quarter immediately prior to the } \\
\text { announcement }\end{array}$ & 13-F Thomson Reuters \\
\hline Dedicated institutional investors & INSDED & $\begin{array}{l}\text { The number of shares held by dedicated institutional investors divided by the total number of } \\
\text { shares outstanding in the firm }\end{array}$ & GMI Rating \\
\hline Active institutional investors & INSACTIVE & $\begin{array}{l}\text { The number of shares held by quasi institutional investors and dedicated investors divided by } \\
\text { the total number of shares outstanding in the firm }\end{array}$ & GMI Rating \\
\hline Transient institutional investors & INSTRA & $\begin{array}{l}\text { The number of shares held by transient institutional investors divided by the total number of } \\
\text { shares outstanding in the firm }\end{array}$ & GMI Rating \\
\hline
\end{tabular}




\section{References}

Aggarwal, R., Erel, I., Ferreira, M., Matos, P. 2011. Does governance travel around the world? Evidence from institutional investors. Journal of Financial Economics 100(1), 154-181.

Autore, D.M., Hutton, I., Kovacs, T., 2011. Accelerated equity offers and firm quality. European Financial Management 17, 835-859.

Beasley, M.S., 1996. An empirical analysis of the relation between the board of director composition and financial statement fraud. Accounting Review, 443-465.

Bertrand, M., Schoar, A., 2003. Managing with style: The effect of managers on firm policies. Quarterly Journal of Economics 118, 1169-1208.

Bortolotti, B., Megginson, W., Smart, S.B., 2008. The rise of accelerated seasoned equity underwritings. Journal of Applied Corporate Finance 20, 35-57.

Bowen, R., Chen, X., Cheng, Q., 2008. Analyst coverage and the cost of raising equity capital: Evidence from underpricing of seasoned equity offerings. Contemporary Accounting Research 25, 657-699.

Brown, S., Hillegeist, S.A., 2007. How disclosure quality affects the level of information asymmetry. Review of Accounting Studies, 12(2-3), 443-477.

Burns, N., Kedia, S., Lipson, M., 2010. Institutional ownership and monitoring: Evidence from financial misreporting. Journal of Corporate Finance 16, 443-455.

Bushee, B.J., 2001. Do institutional investors prefer near-term earnings over long-run value?. Contemporary Accounting Research 18, 207-246.

Chang, X., Dasgupta, S., Hilary, G., 2006. Analyst Coverage and Financing Decisions. Journal of Finance 61, 3009-3048.

Chemmanur, T.J., 1993. The pricing of initial public offerings: A dynamic model with information production. Journal of Finance 48, 285-304.

Chemmanur, T.J., He, S., Hu, G., 2009. The role of institutional investors in seasoned equity offerings. Journal of Financial Economics 94, 384-411.

Chemmanur, T.J., Paeglis, I., 2005. Management quality, certification, and initial public offerings. Journal of Financial Economics 76, 331-368.

Chemmanur, T.J., Paeglis, I., Simonyan, K., 2010. Management quality, financial and investment policies, and asymmetric information. Journal of Financial and Quantitative Analysis 44, 1045-1079.

Chen, X., Harford, J., and Li, K., 2007. Monitoring: Which institutions matter? Journal of Financial Economics 86, 279-305.

Croci, E., Petmezas, D. 2015. Do risk-taking incentives induce CEOs to invest? Evidence from acquisitions. Journal of Corporate Finance 32, 1-23.

Cronqvist, H., Nilsson, M., 2005. The choice between rights offerings and private equity placements. Journal of Financial Economics 78, 375-407.

Dalton, D.R., Hitt, M.A., Certo, S.T., Dalton, C.M., 2007. The fundamental agency problem and its mitigation: independence, equity, and the market for corporate control. Academy of Management Annals 1(1), 1-64.

Dang, T.L., Huynh, T.H.H, Nguyen, M.T., Nguyen, T.M.H., 2017. Firm environments and capital structure: International evidence. Applied Economics 49: 4482-4500.

Demerjian, P.R., Lev, B., Lewis, M.F., McVay, S.E., 2013. Managerial ability and earnings quality. Accounting Review 88, 463-498. 
Demerjian, P., Lev, B., McVay, S., 2012. Quantifying managerial ability: A new measure and validity tests. Management Science 58, 1229-1248.

Demsetz, H., Lehn, K., 1985. The Structure of Corporate Ownership: Causes and Consequences. Journal of Political Economy 93, 1155-1177.

Fama, E.F., Jensen, M.C., 1983. Separation of ownership and control. Journal of Law and Economics, 301-325.

Fee, C.E., Hadlock, C.J., 2003. Raids, rewards, and reputations in the market for managerial talent. Review of Financial Studies 16, 1315-1357.

Ferreira, M.A., Matos, P., 2008. The colors of investors' money: The role of institutional investors around the world. Journal of Financial Economics 88, 499-533.

Ferreira, M.A., Massa, M., Matos, P., 2010. Shareholders at the gate? Institutional investors and cross-border mergers and acquisitions. Review of Financial Studies 23, 601-644.

Finkelstein, S., D'aveni, R.A., 1994. CEO duality as a double-edged sword: How boards of directors balance entrenchment avoidance and unity of command. Academy of Management Journal 37, 1079-1108.

Gao, X., Ritter, J., 2010. The marketing of seasoned equity offerings. Journal of Financial Economics 97, 33-52.

Gibson, S., Safieddine, A., Sonti, R., 2004. Smart investments by smart money: Evidence from seasoned equity offerings. Journal of Financial Economics 72(3), 581-604.

Gillan, S.L., Starks, L.T., 2003. Corporate governance, corporate ownership, and the role of institutional investors: A global perspective. Journal of Applied Finance 12, 4-22.

Goyal, V. K., Park, C.W., 2002. Board leadership structure and CEO turnover. Journal of Corporate Finance 8, 49-66.

Hao, Q., 2014. Institutional shareholder investment horizons and seasoned equity offerings. Financial Management 43, 87-111.

Hartzell, J.C., Starks, L.T., 2003. Institutional investors and executive compensation. Journal of Finance 58, 2351-2374.

Heron, R., Lie, E., 2004. A comparison of the motivations for and the information content of different types of equity offerings. Journal of Business 77, 605-632.

Jensen, M.C., Meckling, W.H., 1976. Theory of the firm: Managerial behavior, agency costs and ownership structure. Journal of Financial Economics, 3, 305-360.

Jensen, M.C., Ruback, R.S., 1983. The market for corporate control: The scientific evidence. Journal of Financial Economics 11, 5-50.

Kim, J.B, Li, L., Lu, L., Yu, Y., 2016. Financial statement comparability and expected crash risk. Journal of Accounting and Economics, 61, 294-312.

Koerniadi, H., Krishnamurti, C., Lau, S.T., Tourani-Rad, A., Yang, T.. 2015. The role of internal and external certification mechanisms in seasoned equity offerings. Journal of Multinational Financial Management, 30, 110-127.

Koerniadi, H., Tourani-Rad, A., 2012. Does board independence matter? Evidence from New Zealand. Australasian Accounting, Business and Finance Journal 6, 3-18.

Leverty, J.T., Grace, M.F., 2012. Dupes or incompetents? An examination of management's impact on firm distress. Journal of Risk and Insurance 79, 751-783.

Malmendier, U., Tate, G., 2005. CEO overconfidence and corporate investment. Journal of Finance 60, 2661-2700. 
Mallette, P., Hogler, R.L., 1995. Board composition, stock ownership and the exemption of directors from liability. Journal of Management 21, 861-878.

McNulty, T., Pettigrew, A., 1999. Strategists on the board. Organization studies, 20, 47-74.

Milbourn, T. T., 2003. CEO reputation and stock-based compensation. Journal of Financial Economics 68, 233-262.

Pandes, J.A., 2010. Bought deals: The value of underwriter certification in seasoned equity offerings. Journal of Banking and Finance 34, 1576-1589.

Shleifer, A.,Vishny, R.W., 1986. Large shareholders and corporate control. Journal of Political Economy 94, 461-488.

Sundaramurthy C., 1996. Corporate governance within the context of antitakeover provisions. Strategic Management Journal 17, 377-394.

Switzer, L.N., Bourdon, J.F., 2011. Management quality and operating performance: Evidence for Canadian IPOs. International Journal of Business 16, 133.

Tihanyi, L., Johnson, R.A., Hoskisson, R.E., Hitt, M.A., 2003. Institutional ownership differences and international diversification: the effects of boards of directors and technological opportunity. Academy of Management Journal 46, 195-211.

Tuggle, C.S., Sirmon, D.G., Reutzel, C.R., Bierman, L., 2010. Commanding board of director attention: investigating how organizational performance and CEO duality affect board members' attention to monitoring. Strategic Management Journal 31, 946-968. 
Table 1: Summary of sample selection and data filtering

\begin{tabular}{lc}
\hline Reason for Sample Exclusion & No. of offerings \\
\hline Initial Sample of US SEOs & 17,289 \\
Less Exclusions & \\
Without Shelf offering details & 7,433 \\
IPO offering & 1,917 \\
Duplication offering & 1,668 \\
American Depositary Share (ADS) & 02 \\
Warrants & 182 \\
Convertible Bonds & 435 \\
Preference shares & 52 \\
Trust Units & 513 \\
Units & 680 \\
Without Firm codes/announcement details & 220 \\
Without Total asset and Market Value & 655 \\
Without Return Series Data for one year & 530 \\
Without Offering Proceeds Data in SDC & 366 \\
Without MA measure & 974 \\
Rights offering and Private Placement & 094 \\
Total Exclusions & 15,771 \\
Final Sample & $\mathbf{1 , 5 6 8}$ \\
\hline
\end{tabular}

Table 2: Summary of sample selection and distribution

Panel A provides year-wise distribution of accelerated SEOs and firm commitment SEOs in the period 20012013. Panel B reports percentage distribution of SEOs in our final sample. Panel C provides industry-wise distribution of SEO offerings.

\begin{tabular}{|c|c|c|c|}
\hline \multicolumn{4}{|c|}{ Panel A: Year-wise classification } \\
\hline Year & Accelerated SEOs & Firm Commitment SEOs & Total \\
\hline 2001 & 6 & 88 & 94 \\
\hline 2002 & 11 & 114 & 125 \\
\hline 2003 & 22 & 139 & 161 \\
\hline 2004 & 31 & 118 & 149 \\
\hline 2005 & 18 & 86 & 104 \\
\hline 2006 & 13 & 92 & 105 \\
\hline 2007 & 5 & 103 & 108 \\
\hline 2008 & 5 & 69 & 74 \\
\hline 2009 & 5 & 166 & 171 \\
\hline 2010 & 9 & 122 & 131 \\
\hline 2011 & 20 & 105 & 125 \\
\hline 2012 & 22 & 104 & 126 \\
\hline 2013 & 21 & 74 & 095 \\
\hline Total & 188 & 1,380 & 1,568 \\
\hline \multicolumn{4}{|c|}{ Panel B: Type of SEO offering } \\
\hline pes of offering & & Total & In Percentage $(\%)$ \\
\hline celerated offering & & 188 & 11.98 \\
\hline m Commitment & & 1380 & 88.02 \\
\hline \multicolumn{4}{|c|}{ Panel C: Industry-based classification } \\
\hline dustry & & Total & In Percentage (\%) \\
\hline vice & & 9 & 0.54 \\
\hline riculture & & 219 & 13.17 \\
\hline ansportation & & 92 & 5.56 \\
\hline nstruction & & 361 & 21.72 \\
\hline lance & & 60 & 3.61 \\
\hline anufacturing & & 629 & 37.84 \\
\hline ning & & 39 & 2.34 \\
\hline tail & & 252 & 15.16 \\
\hline holesale & & 1 & 0.06 \\
\hline
\end{tabular}




\section{Table 3: SEOs issuance decisions and firm characteristics}

This table reports summary statistics of firm-level financial characteristics related to accelerated versus firm commitment SEOs in our sample. The table also provides nonparametric test statistics, the Mann-Whitney (MW) test for the difference in median values across the two groups of SEOs. These firm-level financial characteristics are the following: SIZE, the total assets at the balance sheet date immediately prior to the announcement date; $M V$, the market value of the issuing firm one month prior to the announcement; LEVERAGE, the ratio of the total debt to total assets; $B M$, the book-to-market ratio measured as the ratio of the book value of assets to market value of assets; $A G E$, the company age from its listing date (years); $S D V O L$, standard deviation of monthly return calculated for each firm each year; SDEAR, standard deviation of EBITDA to asset ratio over a 10 -year period; ATGROWTH, change in the log of total assets; PREPBAIYR, average proportionate bid-ask spread for one year period prior to the announcement; TANGIBILITY, Net PPE-to-assets ratio; $M A$, managerial ability measure constructed by Demerjian et al. (2012); $O P$, offering proceeds; OPTOTA, offer proceeds relative to total assets; PREPRICE, median monthly closing prices over a 12-month period; IDYRISK, the standard error for the 1-year period before the announcement date (return from day t-260 today t2); TACCURAL, total accruals; CEODUAL, a dummy variable which takes the value of one if the CEO of the firm is also the chairman of the board; BSIZE, the number of board members; INDEP, the percentage of nonexecutive directors on the board. BMEETS, the total number of board meetings in a year; DGENDER, a dummy variable which takes a value of one if there is at least one female director on the board and zero otherwise; INSDED, the number of shares held by dedicated institutional investors divided by the total number of shares outstanding in the firm; INSQUASI, the number of shares held by quasi institutional investors divided by the total number of shares outstanding in the firm; INSTRA, the number of shares held by transient institutional investors divided by the total number of shares outstanding in the firm. The symbols ***, ** and * indicate significance at the $1 \%, 5 \%$ and $10 \%$ levels, respectively.

\begin{tabular}{|c|c|c|c|c|}
\hline Variables & Statistics & $\begin{array}{c}\text { Accelerated } \\
\text { SEOs }\end{array}$ & $\begin{array}{c}\text { Firm } \\
\text { Commitment } \\
\text { SEOs }\end{array}$ & MW test \\
\hline \multirow[t]{2}{*}{$\operatorname{SIZE}(\$ m)$} & Mean & 4724.14 & 2374.04 & \\
\hline & Median & 793.23 & 300.86 & $6.05 * * *$ \\
\hline \multirow[t]{2}{*}{$M V(\$ m)$} & Mean & 2302.61 & 1768.46 & \\
\hline & Median & 724.20 & 391.96 & $5.58 * * *$ \\
\hline \multirow[t]{2}{*}{ LEVERAGE } & Mean & 34.36 & 25.67 & \\
\hline & Median & 31.77 & 20.60 & $4.11 * * *$ \\
\hline \multirow[t]{2}{*}{$B M$} & Mean & 0.62 & 0.58 & \\
\hline & Median & 0.66 & 0.55 & $2.43 * *$ \\
\hline \multirow[t]{2}{*}{$A G E$} & Mean & 13.43 & 11.65 & \\
\hline & Median & 8.59 & 7.79 & $1.98 * *$ \\
\hline \multirow[t]{2}{*}{$S D V O L$} & Mean & 0.03 & 0.04 & \\
\hline & Median & 0.02 & 0.03 & $5.76^{* * *}$ \\
\hline \multirow[t]{2}{*}{ SDEAR } & Mean & -0.08 & -0.09 & \\
\hline & Median & 0.04 & 0.03 & 0.90 \\
\hline \multirow[t]{2}{*}{ ATGROWTH } & Mean & 19.23 & 18.79 & \\
\hline & Median & 12.54 & 9.88 & 0.51 \\
\hline \multirow[t]{2}{*}{ PREPBAIYR } & Mean & 0.71 & 1.17 & \\
\hline & Median & 0.32 & 0.65 & $5.90 * * *$ \\
\hline \multirow[t]{2}{*}{ TANGIBILITY } & Mean & 30.79 & 26.30 & \\
\hline & Median & 19.10 & 15.33 & 0.95 \\
\hline \multirow[t]{2}{*}{$M A$} & Mean & 0.02 & -0.03 & \\
\hline & Median & -0.02 & -0.04 & 1.05 \\
\hline \multirow[t]{2}{*}{$O P(\$ m)$} & Mean & 219.73 & 188.14 & \\
\hline & Median & 119.95 & 90.00 & $4.68 * * *$ \\
\hline \multirow[t]{2}{*}{ PREPRICE } & Mean & 20.13 & 17.10 & \\
\hline & Median & 16.00 & 12.52 & $2.74 * * *$ \\
\hline \multirow[t]{2}{*}{ IDYRISK } & Mean & 0.02 & 0.03 & \\
\hline & Median & 0.02 & 0.03 & $6.45 * * *$ \\
\hline \multirow[t]{2}{*}{ INSOWN } & Mean & 41.56 & 36.22 & \\
\hline & Median & 40.60 & 30.64 & 1.16 \\
\hline \multirow[t]{2}{*}{ TACCURAL } & Mean & -0.09 & -0.10 & \\
\hline & Median & -0.05 & -0.07 & $2.04 * *$ \\
\hline ОРТОТА & Mean & 37.04 & 51.33 & \\
\hline
\end{tabular}




\begin{tabular}{llccc}
\hline & Median & 18.40 & 28.71 & $4.61^{* * *}$ \\
INSDED & Mean & 18.60 & 8.02 & \\
& Median & 15.96 & 6.23 & $4.32^{* * *}$ \\
INSQUASI & Mean & 23.54 & 19.54 & $3.65^{* * *}$ \\
& Median & 20.89 & 17.24 & \\
INSTRA & Mean & 16.54 & 17.05 & $1.87^{*}$ \\
& Median & 15.41 & 15.23 & \\
INDEDEAL & Mean & 0.63 & 0.62 & 1.03 \\
BSIZE & Median & 1.00 & 1.00 & 1.22 \\
& Mean & 57.08 & 56.25 & $2.57^{* *}$ \\
BMEETS & Median & 58.00 & 56.50 & \\
& Mean & 14.63 & 14.59 & 0.89 \\
DGENDER & Median & 13.00 & 13.00 & \\
& Mean & 1.87 & 1.23 & 0.23 \\
\hline
\end{tabular}




\section{Table 4: Managerial ability and SEO issuance decisions}

This table presents the empirical analysis results of the relation between firm-level managerial ability and SEO issuance decisions. The empirical probit model is given as:

$$
\text { SEOchoice }_{i, t}=\alpha+\beta M A_{i, t-1}+\gamma \text { Controls }_{i, t-1}+\varepsilon_{i, t}
$$

where, SEOchoice ${ }_{i, t}$ is a dummy variable taking the value of one if the firm offers accelerated SEOs, otherwise zero for firm commitment SEOs. We employ the managerial ability score developed by Demerjian et al. (2012) to proxy for managerial ability $\left(M A_{i, t-1}\right)$. This study further employs a number of other firm-level control variables $\left(\right.$ Controls $\left._{i, t-1}\right)$ that could potentially influence firms' SEO choices. All control variables are measured over or at the end of the previous year, and winsorized at 1\%, including firm size (SIZE), liquidity (LIQUID), risk (IDYRISK), relative issue size (OPTOTA), shelf offering (DSHELF, DSHELF_1), age (AGE), book-tomarket ratio $(B M)$, and leverage $(L E V E R A G E)$. The construction of the related variables is detailed in the Appendix. Year and industry dummies are also included to control for year-industry fixed effects. The $z$ statistics shown in parentheses are based on robust standard errors. The symbols ***, ** and * indicate significance at the $1 \%, 5 \%$ and $10 \%$ levels, respectively.

\begin{tabular}{|c|c|c|c|c|c|c|}
\hline \multirow[b]{2}{*}{ Variables } & \multicolumn{6}{|c|}{ Accelerated SEOs vs. Firm Commitment SEOs } \\
\hline & (1) & (2) & (3) & (4) & (5) & (6) \\
\hline$M A$ & $\begin{array}{c}1.470 \\
(3.51)^{* * *}\end{array}$ & $\begin{array}{c}1.114 \\
(2.52)^{* *}\end{array}$ & $\begin{array}{c}1.311 \\
(2.98)^{* * * *}\end{array}$ & $\begin{array}{c}1.306 \\
(2.97) * * *\end{array}$ & $\begin{array}{c}1.534 \\
(3.57)^{* * *}\end{array}$ & $\begin{array}{c}1.080 \\
(2.43)^{* *}\end{array}$ \\
\hline SIZE & & $\begin{array}{c}0.292 \\
(4.47)^{* * *}\end{array}$ & & & & $\begin{array}{c}0.207 \\
(2.17)^{* *}\end{array}$ \\
\hline$L I Q U I D$ & & & $\begin{array}{c}-0.395 \\
(-4.10)^{* * *}\end{array}$ & & & $\begin{array}{l}-0.153 \\
(-1.10)\end{array}$ \\
\hline IDYRISK & & & & $\begin{array}{c}-16.110 \\
(-2.48)^{* *}\end{array}$ & & $\begin{array}{l}-3.854 \\
(-0.65)\end{array}$ \\
\hline OРТОТА & & & & & $\begin{array}{l}-0.221 \\
(-0.93)\end{array}$ & $\begin{array}{l}-0.002 \\
(-0.02)\end{array}$ \\
\hline DSHELF & & $\begin{array}{c}1.074 \\
(1.88)^{*}\end{array}$ & $\begin{array}{c}1.226 \\
(2.15)^{* *}\end{array}$ & $\begin{array}{c}1.413 \\
(2.51)^{* *}\end{array}$ & $\begin{array}{c}1.515 \\
(2.61)^{* * *}\end{array}$ & $\begin{array}{c}1.016 \\
(1.75)^{*}\end{array}$ \\
\hline$A G E$ & & $\begin{array}{l}0.042 \\
(0.49)\end{array}$ & $\begin{array}{l}0.068 \\
(0.79)\end{array}$ & $\begin{array}{l}0.083 \\
(0.98)\end{array}$ & $\begin{array}{c}0.098 \\
(1.14)\end{array}$ & $\begin{array}{c}0.0422 \\
(0.49)\end{array}$ \\
\hline$B M$ & & $\begin{array}{l}0.022 \\
(0.11)\end{array}$ & $\begin{array}{c}0.424 \\
(2.26)^{* *}\end{array}$ & $\begin{array}{l}0.289 \\
(1.54)\end{array}$ & $\begin{array}{l}0.232 \\
(1.10)\end{array}$ & $\begin{array}{l}0.135 \\
(0.57)\end{array}$ \\
\hline LEVERAGE & & $\begin{array}{c}0.587 \\
(1.89)^{*}\end{array}$ & $\begin{array}{c}0.827 \\
(2.75)^{* * *}\end{array}$ & $\begin{array}{c}0.904 \\
(3.11)^{* * *}\end{array}$ & $\begin{array}{c}0.875 \\
(3.09)^{* * *}\end{array}$ & $\begin{array}{c}0.646 \\
(2.06)^{* *}\end{array}$ \\
\hline DSHELF_l & & $\begin{array}{l}-0.782 \\
(-1.30)\end{array}$ & $\begin{array}{l}-0.635 \\
(-1.04)\end{array}$ & $\begin{array}{l}-0.486 \\
(-0.79)\end{array}$ & $\begin{array}{l}-0.394 \\
(-0.63)\end{array}$ & $\begin{array}{l}-0.836 \\
(-1.36)\end{array}$ \\
\hline CONSTANT & $\begin{array}{l}-1.104 \\
(-1.01)\end{array}$ & $\begin{array}{c}-3.811 \\
(-3.76) * * *\end{array}$ & $\begin{array}{c}-2.216 \\
(-2.19)^{* *}\end{array}$ & $\begin{array}{c}-1.958 \\
(-1.84)^{*}\end{array}$ & $\begin{array}{c}-2.638 \\
(-2.51)^{* *}\end{array}$ & $\begin{array}{c}-3.081 \\
(-2.69) * * *\end{array}$ \\
\hline Pseudo-R ${ }^{2}$ & 0.070 & 0.164 & 0.160 & 0.152 & 0.147 & 0.166 \\
\hline Fixed effects & YI & YI & YI & YI & YI & YI \\
\hline Obs & 1,568 & 1,568 & 1,568 & 1,568 & 1,568 & 1,568 \\
\hline
\end{tabular}




\section{Table 5: Information environments, managerial ability and SEO decisions}

This table reports the impact of the degree of information asymmetry on the relation between managerial ability and accelerated offering decisions. We use analyst coverage, firm R\&D Intensity, and analyst dispersion, as proxies for information asymmetry. We sort all firms in our sample into three groups for each fiscal year: a high information environment group (that is, with low information asymmetry) and a low information environment group (high information asymmetry) based on the median values of financial analysts following and analyst forecast dispersion for each year, and an $R \& D$ intensive industry or otherwise classification. In the case of financial analysts, we define the high information environment group as firms having more analysts following than the median analysts following for each year of our sample (HighANALYSTS) whereas the low information environment group is defined as firms having a lower than or equal to median analysts following (LowANALYSTS). Similarly, we classify firms into the high information environment category for firms with lower than median analyst forecast dispersion for each year (LowDISP) and the low information environment category contains firms with higher than or equal to the median (HighDISP). R\&D intensive firms are classified as firms operating in the chemical and pharmaceutical, machinery and computer hardware, electricity and electronics and scientific instruments industries. We employ the managerial ability score developed by Demerjian et al. (2012) to proxy for managerial ability $\left(M A_{i, t-1}\right)$. We further employ a number of other firm-level control variables (Controls ${ }_{i, t-1}$ ) that could potentially influence firms' SEO choices. All control variables are measured over or at the end of the previous year, and winsorized at $1 \%$ and $99 \%$ levels, including firm size (SIZE), liquidity (LIQUID), risk (IDYRISK), relative issue size (OPTOTA), shelf offering (DSHELF, DSHELF_l), age $(A G E)$, book-to-market ratio $(B M)$, and leverage (LEVERAGE). The construction of the related variables is detailed in the Appendix. Year and industry dummies are also included to control for yearindustry fixed effects. The symbols ***, **, and * denote significance levels at the $1 \%, 5 \%$, and $10 \%$ levels, respectively.

\begin{tabular}{|c|c|c|}
\hline \multicolumn{3}{|c|}{ Panel A: R\&D Intensive Industry } \\
\hline Variables & $R \& D I N T E N S I V E$ & Non-R\&DINTENSIVE \\
\hline \multirow[t]{2}{*}{$M A$} & 0.608 & 0.060 \\
\hline & $(2.02) * *$ & $(0.12)$ \\
\hline \multirow[t]{2}{*}{ CONSTANT } & -2.375 & -2.386 \\
\hline & $(-3.29) * * *$ & $(-3.03) * * *$ \\
\hline All control variables & Yes & Yes \\
\hline Fixed effects & YI & YI \\
\hline Pseudo $R^{2}$ & 0.215 & 0.154 \\
\hline Obs & 645 & 923 \\
\hline \multicolumn{3}{|c|}{ Panel B: Financial analysts } \\
\hline & HighANALYSTS & LowANALYSTS \\
\hline \multirow[t]{2}{*}{$M A$} & 0.432 & 0.953 \\
\hline & $(1.38)$ & $(2.75) * * *$ \\
\hline \multirow[t]{2}{*}{ CONSTANT } & -3.089 & -3.385 \\
\hline & $(-4.18) * * *$ & $(-3.62)^{* * *}$ \\
\hline All control variables & Yes & Yes \\
\hline Fixed effects & YI & YI \\
\hline Pseudo $R^{2}$ & 0.181 & 0.211 \\
\hline Obs & 886 & 631 \\
\hline \multicolumn{3}{|c|}{ Panel C: Analysts forecast dispersion } \\
\hline & HighDISP & LowDISP \\
\hline \multirow[t]{2}{*}{$M A$} & 0.491 & 0.306 \\
\hline & $(2.64) * * *$ & (1.09) \\
\hline \multirow[t]{2}{*}{ CONSTANT } & -3.403 & -2.754 \\
\hline & $(-5.62)^{* * *}$ & $(-2.74) * * *$ \\
\hline All control variables & Yes & Yes \\
\hline Fixed effects & YI & YI \\
\hline Pseudo $R^{2}$ & 0.249 & 0.150 \\
\hline Obs & 561 & 860 \\
\hline
\end{tabular}




\section{Table 6: PSM approach to address endogeneity}

This table presents the empirical analysis results of propensity score matching (PSM) approach to examine whether firms with higher managerial ability prefer accelerated offering decision. We use the yearly two-digit SIC industry median of the managerial ability measures as the cut-off value and define firms with high (low) managerial ability as those with above- (below-) median managerial ability. The propensity score matching procedure is employed to obtain a sample of firms with a similar likelihood of employing managers with different ability. We consider high ability managers as the top quintile of managerial ability, and low ability managers as the bottom quintile of managerial ability, and examine differences between the two groups' SEO issuance decisions before and after matching. We create a control group based on propensity score matching using firm-level characteristics. Firms with high managerial ability are our treatment firms, whereas firms with low managerial ability are our control firms. We then examine the relation between managerial ability and the SEO choice for this matched sample of firms. The symbols $* * *, * *$ and * indicate significance at the $1 \%, 5 \%$ and $10 \%$ levels, respectively.

\begin{tabular}{lc}
\hline High ability Managers vs. low ability Managers & $\mathbf{0 . 4 5 2}$ \\
& $(\mathbf{3 . 0 5})^{* * *}$ \\
Pseudo $R^{2}$ & 0.1737 \\
Number of firm-year observations in the treatment group & 744 \\
\hline
\end{tabular}

\section{Table 7: Impact of managerial ability on the issuance choice of SEOs using firm-fixed effect models}

This table presents the empirical analysis results of the relation between firm-level managerial ability and SEO issuance decisions using firm-fixed effect models. The dependent variable, SEOchoice $i, t$ is a dummy variable taking the value of one if the firm offers accelerated SEOs, otherwise zero for firm commitment SEOs. We employ the managerial ability score developed by Demerjian et al. (2012) to proxy for managerial ability $\left(M A_{i, t-}\right.$ 1). This study further employs a number of other firm-level control variables (Controls $s_{i, t-l}$ ) that could potentially influence firms' SEO choices. All control variables are measured over or at the end of the previous year, and winsorized at $1 \%$, including firm size (SIZE), liquidity (LIQUID), risk (IDYRISK), relative issue size $(O P T O T A)$, shelf offering (DSHELF, DSHELF_l), age $(A G E)$, book-to-market ratio (BM), and leverage (LEVERAGE). The construction of the related variables is detailed in the Appendix. The z-statistics shown in parentheses are based on robust standard errors. The symbols $* * *, * *$ and * indicate significance at the $1 \%, 5 \%$ and $10 \%$ levels, respectively.

\begin{tabular}{|c|c|c|c|c|c|c|}
\hline Variables & (1) & $(2)$ & (3) & $(4)$ & $(5)$ & (6) \\
\hline$M A$ & $\begin{array}{c}\mathbf{1 . 5 5 4} \\
(3.49)^{* * *}\end{array}$ & $\begin{array}{c}1.223 \\
(2.61)^{* * *}\end{array}$ & $\begin{array}{c}1.525 \\
(3.33)^{* * *}\end{array}$ & $\begin{array}{c}1.430 \\
(3.03)^{* * *}\end{array}$ & $\begin{array}{c}\mathbf{1 . 6 5 8} \\
(3.59)^{* * *}\end{array}$ & $\begin{array}{c}1.179 \\
(2.50)^{* *}\end{array}$ \\
\hline SIZE & & $\begin{array}{c}0.293 \\
(4.26)^{* * *}\end{array}$ & & & & $\begin{array}{c}0.248 \\
(3.03)^{* * *}\end{array}$ \\
\hline$L I Q U I D$ & & & $\begin{array}{c}-0.300 \\
(-2.54)^{* *}\end{array}$ & & & $\begin{array}{l}-0.073 \\
(-0.62)\end{array}$ \\
\hline IDYRISK & & & & $\begin{array}{c}-16.061 \\
(-2.47)^{* *}\end{array}$ & & $\begin{array}{l}-4.983 \\
(-0.76)\end{array}$ \\
\hline OРТОТА & & & & & $\begin{array}{l}-0.196 \\
(-1.09)\end{array}$ & $\begin{array}{l}-0.017 \\
(-0.13)\end{array}$ \\
\hline DSHELF & & $\begin{array}{c}1.796 \\
(6.02)^{* * *}\end{array}$ & $\begin{array}{c}1.807 \\
(6.09)^{* * *}\end{array}$ & $\begin{array}{c}1.874 \\
(6.27)^{* * *}\end{array}$ & $\begin{array}{c}1.907 \\
(6.36)^{* * *}\end{array}$ & $\begin{array}{c}1.777 \\
(5.94)^{* * *}\end{array}$ \\
\hline$A G E$ & & $\begin{array}{l}0.030 \\
(0.33)\end{array}$ & $\begin{array}{l}0.087 \\
(0.97)\end{array}$ & $\begin{array}{l}0.074 \\
(0.81)\end{array}$ & $\begin{array}{l}0.090 \\
(0.98)\end{array}$ & $\begin{array}{l}0.032 \\
(0.36)\end{array}$ \\
\hline$B M$ & & $\begin{array}{l}0.010 \\
(0.05)\end{array}$ & $\begin{array}{c}0.398 \\
(2.23)^{* *}\end{array}$ & $\begin{array}{l}0.286 \\
(1.58)\end{array}$ & $\begin{array}{l}0.244 \\
(1.25)\end{array}$ & $\begin{array}{l}0.066 \\
(0.32)\end{array}$ \\
\hline LEVERAGE & & $\begin{array}{c}0.666 \\
(1.97)^{* *}\end{array}$ & $\begin{array}{c}0.945 \\
(2.95)^{* * *}\end{array}$ & $\begin{array}{c}0.994 \\
(3.10)^{* * *}\end{array}$ & $\begin{array}{c}0.978 \\
(3.03)^{* * *}\end{array}$ & $\begin{array}{c}0.699 \\
(2.06)^{* *}\end{array}$ \\
\hline DSHELF_l & $\begin{array}{l}-0.624 \\
(-1.35)\end{array}$ & $\begin{array}{l}-0.910 \\
(-1.57)\end{array}$ & $\begin{array}{l}-0.401 \\
(-0.69)\end{array}$ & $\begin{array}{l}-0.565 \\
(-0.97)\end{array}$ & $\begin{array}{l}-0.774 \\
(-1.34)\end{array}$ & $\begin{array}{l}-0.727 \\
(-1.20)\end{array}$ \\
\hline CONSTANT & $\begin{array}{c}-2.839 \\
(-5.07)^{* * *}\end{array}$ & $\begin{array}{c}-6.383 \\
(-7.31)^{* * *}\end{array}$ & $\begin{array}{c}-3.675 \\
(-5.24)^{* * *}\end{array}$ & $\begin{array}{c}-3.702 \\
(-5.17)^{* * *}\end{array}$ & $\begin{array}{c}-4.320 \\
(-6.33)^{* * *}\end{array}$ & $\begin{array}{c}-5.717 \\
(-5.37)^{* * *}\end{array}$ \\
\hline Fixed effects & FYI & FYI & FYI & FYI & FYI & FYI \\
\hline Wald Chi 2 & $60.25 * * *$ & $109.50 * * *$ & $107.19 * * *$ & $104.75 * * *$ & $102.52 * * *$ & $109.98 * * *$ \\
\hline Obs & 1,568 & 1,568 & 1,568 & 1,568 & 1,568 & 1,568 \\
\hline
\end{tabular}


Table 8: Managerial ability, endogeneity and equity issuance choice

This table presents the empirical analysis results of the relation between managerial ability and SEO issuance decisions using instrumental variable regressions. In the first-stage regression, we employ an ordinary least squares model to predict the managerial ability. In the second-stage regression, we examine the SEO choice using the managerial ability predicted from the first-stage regression and other controls used in our baseline regression. We employ an instrumental variable that relates to the firm's managerial ability but are directly driving its SEO choice. Our instrumental variable is the Industry-median MA Score (based on SIC 2 digit industry classification). The main test variable in the second-stage regression is predicted MA (EXMA). We report the results for the first-stage regression in Panel A, and the second stage in Panel B. All control variables are measured over or at the end of the previous year, and winsorized at $1 \%$, including firm size (SIZE), liquidity $(L I Q U I D)$, risk (IDYRISK), relative issue size (OPTOTA), shelf offering (DSHELF, DSHELF_l), age (AGE), book-to-market ratio $(B M)$, and leverage (LEVERAGE). The construction of the related variables is detailed in the Appendix. The z-statistics shown in parentheses are based on robust standard errors. The symbols $* * *, * *$ and $*$ indicate significance at the $1 \%, 5 \%$ and $10 \%$ levels, respectively.

\begin{tabular}{lc} 
Panel A: First-stage regression on the relation between \\
MA and Industry-median MA Score \\
\hline Industry-median MA Score \\
SIZE & $\mathbf{0 . 9 5 9}$ \\
& $(\mathbf{3 7 . 3 0})^{* * *}$ \\
LIQUID & 0.019 \\
& $(5.96)^{* * *}$ \\
IDYRISK & 0.009 \\
& $(2.95)^{* * *}$ \\
OPTOTA & -0.666 \\
& $(-2.74)^{* * *}$ \\
DSHELF & 0.004 \\
& $(1.21)$ \\
BM & -0.018 \\
& $(-2.23)^{* *}$ \\
LEVERAGE & -0.028 \\
& $(-3.50)^{* * *}$ \\
DSHELF_1 & -0.046 \\
& $(-3.65)^{* * *}$ \\
CONSTANT & 0.003 \\
Fixed effects & $(0.15)$ \\
$R^{2}$ & -0.119 \\
Obs & $(-3.64)^{* * *}$ \\
& YI \\
& 0.471 \\
& 1,568 \\
\end{tabular}

Panel B: Second-stage regression on the relation between predicted MA and SEO issuance decisions

\begin{tabular}{|c|c|c|c|c|c|c|}
\hline Variables & (1) & (2) & (3) & (4) & (5) & (6) \\
\hline$E X M A$ & $\begin{array}{c}1.641 \\
(5.05)^{* * *}\end{array}$ & $\begin{array}{c}1.432 \\
(3.92)^{* * * *}\end{array}$ & $\begin{array}{c}1.760 \\
(4.97)^{* * *}\end{array}$ & $\begin{array}{c}1.686 \\
(4.66) * * *\end{array}$ & $\begin{array}{c}1.847 \\
(5.25)^{* * *}\end{array}$ & $\begin{array}{c}1.414 \\
(3.81)^{* * *}\end{array}$ \\
\hline$S I Z E$ & & $\begin{array}{c}0.125 \\
(3.61)^{* * *}\end{array}$ & & & & $\begin{array}{c}0.108 \\
(2.58) * * *\end{array}$ \\
\hline$L I Q U I D$ & & & $\begin{array}{c}-0.112 \\
(-2.19) * *\end{array}$ & & & $\begin{array}{l}-0.031 \\
(-0.58)\end{array}$ \\
\hline IDYRISK & & & & $\begin{array}{c}-5.623 \\
(-1.85)^{*}\end{array}$ & & $\begin{array}{l}-1.496 \\
(-0.47)\end{array}$ \\
\hline ОРТОТА & & & & & $\begin{array}{l}-0.072 \\
(-0.91)\end{array}$ & $\begin{array}{l}0.007 \\
(0.11)\end{array}$ \\
\hline DSHELF & & $\begin{array}{c}0.915 \\
(6.72)^{* * *}\end{array}$ & $\begin{array}{c}0.922 \\
(6.81)^{* * *}\end{array}$ & $\begin{array}{c}0.948 \\
(7.04)^{* * *}\end{array}$ & $\begin{array}{c}0.961 \\
(7.13)^{* * *}\end{array}$ & $\begin{array}{c}0.906 \\
(6.64) * * *\end{array}$ \\
\hline DSHELF_l & & $\begin{array}{c}-0.629 \\
(-2.19)^{* *}\end{array}$ & $\begin{array}{c}-0.469 \\
(-1.66)^{*}\end{array}$ & $\begin{array}{c}-0.485 \\
(-1.73)^{*}\end{array}$ & $\begin{array}{c}-0.550 \\
(-1.94)^{*}\end{array}$ & $\begin{array}{c}-0.586 \\
(-2.01)^{* *}\end{array}$ \\
\hline$A G E$ & & $\begin{array}{l}0.007 \\
(0.16)\end{array}$ & $\begin{array}{l}0.030 \\
(0.65)\end{array}$ & $\begin{array}{l}0.025 \\
(0.54)\end{array}$ & $\begin{array}{l}0.029 \\
(0.64)\end{array}$ & $\begin{array}{l}0.009 \\
(0.20)\end{array}$ \\
\hline
\end{tabular}




\begin{tabular}{|c|c|c|c|c|c|c|}
\hline$B M$ & & $\begin{array}{l}0.004 \\
(0.04)\end{array}$ & $\begin{array}{c}0.160 \\
(1.82)^{*}\end{array}$ & $\begin{array}{l}0.125 \\
(1.43)\end{array}$ & $\begin{array}{l}0.104 \\
(1.11)\end{array}$ & $\begin{array}{l}0.028 \\
(0.28)\end{array}$ \\
\hline \multirow[t]{2}{*}{ LEVERAGE } & & 0.381 & 0.514 & 0.530 & 0.521 & 0.394 \\
\hline & & $(2.26)^{* *}$ & $(3.20) * * *$ & $(3.32)^{* * *}$ & $(3.24)^{* * *}$ & $(2.32)^{* *}$ \\
\hline CONSTANT & $\begin{array}{c}-1.516 \\
(-6.05)^{* * *}\end{array}$ & $\begin{array}{c}-3.152 \\
(-7.80)^{* * *}\end{array}$ & $\begin{array}{c}-2.038 \\
(-6.19)^{* * *}\end{array}$ & $\begin{array}{c}-2.041 \\
(-6.05)^{* * *}\end{array}$ & $\begin{array}{c}-2.268 \\
(-7.22)^{* * *}\end{array}$ & $\begin{array}{c}-2.905 \\
(-5.71)^{* * *}\end{array}$ \\
\hline Fixed effects & YI & YI & YI & YI & YI & YI \\
\hline Pseudo $R^{2}$ & 0.082 & 0.169 & 0.163 & 0.161 & 0.159 & 0.170 \\
\hline Obs & 1,568 & 1,568 & 1,568 & 1,568 & 1,568 & 1,568 \\
\hline
\end{tabular}




\section{Table 9: Managerial ability, CEO duality, and SEO issuance choice}

This table presents the empirical analysis results of the relation between managerial ability in association with CEO duality and SEO issuance decisions. We interact the $M A$ variable with the CEODUAL variable to investigate if CEO duality status affects the positive relation between managerial ability and SEO issuance decisions. Our regression model is given as follows:

SEOchoice $_{i, t}=\alpha+\beta M A_{i, t-1}+\delta C E O D U A L_{i, t-1}+\vartheta M A^{*}$ CEODUAL $_{i, t-1}+\gamma$ Controls $_{i, t-1}+\varepsilon_{i, t}$

where, SEOchoice ${ }_{i, t}$ is a dummy variable taking the value of one if the firm offers accelerated SEOs, otherwise zero for firm commitment SEOs. We employ the managerial ability score developed by Demerjian et al. (2012) to proxy for managerial ability $\left(M A_{i, t-1}\right)$. CEODUAL $L_{i, t-1}$ is a dummy variable taking the value of one if CEO is also the chairman of the board at the time of the issue, and zero otherwise. Control $l_{, t-1}$ denotes the control proxies of firm $i$ in each year $t-1$, which includes firm size (SIZE), liquidity (LIQUID), risk (IDYRISK), relative issue size (OPTOTA), shelf offering (DSHELF, DSHELF_1), age (AGE), book-to-market ratio (BM), and leverage (LEVERAGE). We further employ a number of additional firm-level control variables to proxy for corporate governance mechanism, including independent directors (INDEP), board size (BSIZE), board meeting (BMEETS), female director (DGENDER), and institutional investors (INSOWN). The construction of the related variables is detailed in the Appendix. Year and industry dummies are also included to control for year-industry fixed effects. The $z$-statistics shown in parentheses are based on robust standard errors. The symbols ***, ** and $*$ indicate significance at the $1 \%, 5 \%$ and $10 \%$ levels, respectively.

\begin{tabular}{|c|c|c|c|c|}
\hline & \multicolumn{4}{|c|}{ Accelerated SEOs vs. Firm Commitment SEOs } \\
\hline Variables & (1) & (2) & (3) & (4) \\
\hline MA & $\begin{array}{c}1.661 \\
(2.95)^{* * *}\end{array}$ & & $\begin{array}{c}1.751 \\
(3.13)^{* * *}\end{array}$ & $\begin{array}{c}\mathbf{0 . 8 9 8} \\
(2.12)^{* * *}\end{array}$ \\
\hline CEODUAL & & $\begin{array}{c}-0.455 \\
(-2.15)^{* *}\end{array}$ & $\begin{array}{l}-0.494 \\
(-1.69) *\end{array}$ & $\begin{array}{c}-0.652 \\
(-1.88) *\end{array}$ \\
\hline$M A * C E O D U A L$ & & & & $\begin{array}{c}2.576 \\
(1.65)^{*}\end{array}$ \\
\hline$I N D E P$ & $\begin{array}{l}-0.021 \\
(-0.05)\end{array}$ & $\begin{array}{l}-0.038 \\
(-0.12)\end{array}$ & $\begin{array}{l}0.035 \\
(0.08)\end{array}$ & $\begin{array}{l}-0.047 \\
(-0.12)\end{array}$ \\
\hline$B S I Z E$ & $\begin{array}{l}-0.378 \\
(-0.48)\end{array}$ & $\begin{array}{l}-0.250 \\
(-0.44)\end{array}$ & $\begin{array}{l}-0.495 \\
(-0.62)\end{array}$ & $\begin{array}{l}-0.408 \\
(-0.52)\end{array}$ \\
\hline BMEETS & $\begin{array}{l}-0.326 \\
(-1.07)\end{array}$ & $\begin{array}{l}-0.325 \\
(-1.56)\end{array}$ & $\begin{array}{l}-0.372 \\
(-1.21)\end{array}$ & $\begin{array}{l}-0.331 \\
(-1.06)\end{array}$ \\
\hline DGENDER & $\begin{array}{l}0.250 \\
(0.86)\end{array}$ & $\begin{array}{l}-0.027 \\
(-0.13)\end{array}$ & $\begin{array}{l}0.232 \\
(0.79)\end{array}$ & $\begin{array}{l}0.242 \\
(0.82)\end{array}$ \\
\hline INSOWN & $\begin{array}{l}-0.093 \\
(-0.26)\end{array}$ & $\begin{array}{l}0.216 \\
(1.24)\end{array}$ & $\begin{array}{l}-0.075 \\
(-0.21)\end{array}$ & $\begin{array}{l}-0.042 \\
(-0.12)\end{array}$ \\
\hline Fixed effects & YI & YI & YI & YI \\
\hline Baseline controls & Yes & Yes & Yes & Yes \\
\hline Pseudo $R^{2}$ & 0.208 & 0.189 & 0.204 & 0.206 \\
\hline Obs & 622 & 622 & 622 & 622 \\
\hline
\end{tabular}




\section{Table 10: Managerial ability, institutional investors, and SEO issuance choice}

This table presents the empirical analysis results of the relation between managerial ability in association with institutional investors and SEO issuance decisions. The dependent variable is SEOchoice $e_{i, t}$, a dummy variable taking the value of one if the firm offers accelerated SEOs, and zero for firm commitment SEOs. We employ the managerial ability score developed by Demerjian et al. (2012) to proxy for managerial ability. We also use a number of proxies for institutional investors' ownership characteristics, including institutional ownership to share outstanding at the last quarter immediately prior to the announcement (INSOWN); the number of shares held by dedicated institutional investors divided by the total number of shares outstanding in the firm (INSDED); the number of shares held by quasi institutional investors and dedicated investors divided by the total number of shares outstanding in the firm (INSACTIVE); and the number of shares held by Transient institutional investors divided by the total number of shares outstanding in the firm (INDTRA). We report the results in Panels A through D. We further combine together these institutional investors' ownership characteristics in a full model and present the results in Panel E. Control variables include firm size (SIZE), liquidity (LIQUID), risk (IDYRISK), relative issue size (OPTOTA), shelf offering (DSHELF, DSHELF_1), age $(A G E)$, book-to-market ratio $(B M)$, and leverage $(L E V E R A G E)$. The construction of the related variables is detailed in the Appendix. Year and industry dummies are also included to control for year-industry fixed effects. The $z$-statistics shown in parentheses are based on robust standard errors. The symbols ***, ** and * indicate significance at the $1 \%, 5 \%$ and $10 \%$ levels, respectively.

\begin{tabular}{|c|c|c|c|c|c|c|}
\hline \multicolumn{7}{|c|}{ Panel A: Role of institutional ownership (INSOWN) on SEO issuance choice decisions } \\
\hline & \multicolumn{6}{|c|}{ Accelerated SEOs vs. Firm Commitment SEOs } \\
\hline Variables & (1) & (2) & (3) & (4) & (5) & (6) \\
\hline MA & & $\begin{array}{c}0.527 \\
(2.14)^{* *}\end{array}$ & $\begin{array}{c}0.654 \\
(2.66)^{* *}\end{array}$ & $\begin{array}{c}0.652 \\
(2.66) * *\end{array}$ & $\begin{array}{c}0.772 \\
(3.21)^{* * *}\end{array}$ & $\begin{array}{c}0.425 \\
(2.06) * *\end{array}$ \\
\hline INSOWN & $\begin{array}{l}0.150 \\
(0.64)\end{array}$ & $\begin{array}{l}0.104 \\
(0.84)\end{array}$ & $\begin{array}{l}0.076 \\
(0.60)\end{array}$ & $\begin{array}{l}0.156 \\
(1.26)\end{array}$ & $\begin{array}{l}0.181 \\
(1.48)\end{array}$ & $\begin{array}{l}0.079 \\
(0.62)\end{array}$ \\
\hline$S I Z E$ & $\begin{array}{c}0.239 \\
(2.50)^{* *}\end{array}$ & $\begin{array}{c}0.167 \\
(4.71)^{* * *}\end{array}$ & & & & $\begin{array}{c}0.126 \\
(2.54)^{* *}\end{array}$ \\
\hline LIQUID & $\begin{array}{l}-0.125 \\
(-0.87)\end{array}$ & & $\begin{array}{c}-0.217 \\
(-4.02)^{* * *}\end{array}$ & & & $\begin{array}{l}-0.075 \\
(-1.02)\end{array}$ \\
\hline IDYRISK & $\begin{array}{l}-6.173 \\
(-0.99)\end{array}$ & & & $\begin{array}{c}-7.848 \\
(-2.47)^{* *}\end{array}$ & & $\begin{array}{l}-1.918 \\
(-0.65)\end{array}$ \\
\hline OPTOTA & $\begin{array}{l}0.017 \\
(0.09)\end{array}$ & & & & $\begin{array}{l}-0.106 \\
(-1.05)\end{array}$ & $\begin{array}{l}0.002 \\
(0.05)\end{array}$ \\
\hline Fixed effects & YI & YI & YI & YI & YI & YI \\
\hline Baseline controls & Yes & Yes & Yes & Yes & Yes & Yes \\
\hline Pseudo-R2 & 0.161 & 0.165 & 0.159 & 0.151 & 0.146 & 0.167 \\
\hline Obs & 1,568 & 1,568 & 1,568 & 1,568 & 1,568 & 1,568 \\
\hline \multicolumn{7}{|c|}{ Panel B: Role of dedicated institutional ownership (INSDED) on SEO issuance choice decisions } \\
\hline & & Accelerated & d SEOs vs. Fir & m Commitm & ent SEOs & \\
\hline Variables & (1) & (2) & (3) & (4) & (5) & (6) \\
\hline MA & & $\begin{array}{c}1.135 \\
(2.57) * *\end{array}$ & $\begin{array}{c}1.338 \\
(3.04)^{* * * *}\end{array}$ & $\begin{array}{c}1.321 \\
(3.01)^{* * * *}\end{array}$ & $\begin{array}{c}1.553 \\
(3.61)^{* * * *}\end{array}$ & $\begin{array}{c}1.100 \\
(2.47)^{* *}\end{array}$ \\
\hline INSDED & $\begin{array}{l}-1.052 \\
(-1.33)\end{array}$ & $\begin{array}{l}-0.998 \\
(-1.30)\end{array}$ & $\begin{array}{l}-0.962 \\
(-1.26)\end{array}$ & $\begin{array}{l}-0.618 \\
(-0.86)\end{array}$ & $\begin{array}{l}-0.436 \\
(-0.62)\end{array}$ & $\begin{array}{l}-1.115 \\
(-1.43)\end{array}$ \\
\hline SIZE & $\begin{array}{c}0.243 \\
(2.54)^{* *}\end{array}$ & $\begin{array}{c}0.305 \\
(4.55)^{* * *}\end{array}$ & & & & $\begin{array}{c}0.213 \\
(2.23)^{* *}\end{array}$ \\
\hline LIQUID & $\begin{array}{l}-0.154 \\
(-1.10)\end{array}$ & & $\begin{array}{c}-0.415 \\
(-4.22)^{* * *}\end{array}$ & & & $\begin{array}{l}-0.168 \\
(-1.20)\end{array}$ \\
\hline IDYRISK & $\begin{array}{l}-6.564 \\
(-1.03)\end{array}$ & & & $\begin{array}{c}-16.752 \\
(-2.51)^{* *}\end{array}$ & & $\begin{array}{l}-4.040 \\
(-0.67)\end{array}$ \\
\hline OPTOTA & $\begin{array}{l}0.004 \\
(0.03)\end{array}$ & & & & $\begin{array}{l}-0.230 \\
(-0.93)\end{array}$ & $\begin{array}{l}-0.007 \\
(-0.06)\end{array}$ \\
\hline Fixed effects & YI & YI & YI & YI & YI & YI \\
\hline Baseline controls & Yes & Yes & Yes & Yes & Yes & Yes \\
\hline Pseudo-R2 & 0.162 & 0.166 & 0.161 & 0.153 & 0.147 & 0.168 \\
\hline Obs & 1,568 & 1,568 & 1,568 & 1,568 & 1,568 & 1,568 \\
\hline
\end{tabular}




\begin{tabular}{|c|c|c|c|c|c|c|}
\hline \multicolumn{7}{|c|}{ Panel C: Role of quasi institutional ownership (INSACTIVE) on SEO issuance choice decisions } \\
\hline & \multicolumn{6}{|c|}{ Accelerated SEOs vs. Firm Commitment SEOs } \\
\hline Variables & (1) & (2) & (3) & (4) & (5) & (6) \\
\hline \multirow[t]{2}{*}{$M A$} & & 0.481 & 0.655 & 0.656 & 0.784 & 0.473 \\
\hline & & $(1.93)^{*}$ & $(2.67)^{* * *}$ & $(2.69) * * *$ & $(3.28)^{* * *}$ & $(1.90)^{*}$ \\
\hline \multirow[t]{2}{*}{ INSACTIVE } & 0.044 & 0.002 & 0.003 & 0.001 & 0.001 & 0.001 \\
\hline & $(0.15)$ & $(1.46)$ & $(1.06)$ & $(0.91)$ & $(0.78)$ & $(1.45)$ \\
\hline \multirow[t]{2}{*}{ SIZE } & 0.140 & 0.189 & & & & 0.147 \\
\hline & $(2.86)^{* * *}$ & $(5.15)^{* * *}$ & & & & $(2.82)^{* * *}$ \\
\hline \multirow[t]{2}{*}{$L I Q U I D$} & -0.073 & & -0.222 & & & -0.070 \\
\hline & $(-0.94)$ & & $(-4.28) * * *$ & & & $(-0.96)$ \\
\hline \multirow[t]{2}{*}{ IDYRISK } & -2.918 & & & -8.148 & & -1.830 \\
\hline & $(-0.93)$ & & & $(-2.59) * * *$ & & $(-0.61)$ \\
\hline \multirow[t]{2}{*}{ OРТОTA } & 0.008 & & & & -0.112 & 0.007 \\
\hline & $(0.15)$ & & & & $(-1.09)$ & $(0.12)$ \\
\hline Fixed effects & YI & YI & YI & YI & YI & YI \\
\hline Baseline controls & Yes & Yes & Yes & Yes & Yes & Yes \\
\hline Pseudo-R2 & 0.163 & 0.165 & 0.161 & 0.150 & 0.144 & 0.168 \\
\hline Obs & 1,568 & 1,568 & 1,568 & 1,568 & 1,568 & 1,568 \\
\hline \multicolumn{7}{|c|}{ Panel D: Role of transient institutional ownership (INSTRA) on SEO issuance choice decisions } \\
\hline & \multicolumn{6}{|c|}{ Accelerated SEOs vs. Firm Commitment SEOs } \\
\hline Variables & (1) & (2) & (3) & (4) & (5) & (6) \\
\hline \multirow[t]{2}{*}{$M A$} & & 1.123 & 1.315 & 1.313 & 1.545 & 1.099 \\
\hline & & $(2.54) * *$ & $(2.99) * * *$ & $(2.99) * * *$ & $(3.59) * * *$ & $(2.47) * *$ \\
\hline \multirow[t]{2}{*}{ INSTRA } & -0.969 & -0.751 & -1.263 & -0.489 & -0.346 & -1.059 \\
\hline & $(-1.30)$ & $(-1.04)$ & $(-1.68)^{*}$ & $(-0.69)$ & $(-0.51)$ & $(-1.40)$ \\
\hline \multirow[t]{2}{*}{ SIZE } & 0.287 & 0.299 & & & & 0.194 \\
\hline & $(2.88) * * *$ & $(4.54)^{* * *}$ & & & & $(2.04) * *$ \\
\hline \multirow[t]{2}{*}{$L I Q U I D$} & -0.170 & & -0.441 & & & -0.208 \\
\hline & $(-1.16)$ & & $(-4.38)^{* * *}$ & & & $(-1.43)$ \\
\hline \multirow[t]{2}{*}{ IDYRISK } & -5.482 & & & -16.482 & & -3.320 \\
\hline & $(-0.86)$ & & & $(-2.48)^{* *}$ & & $(-0.56)$ \\
\hline \multirow[t]{2}{*}{ OРТОTА } & 0.017 & & & & -0.221 & -0.002 \\
\hline & $(0.15)$ & & & & $(-0.94)$ & $(-0.02)$ \\
\hline Fixed effects & YI & YI & YI & YI & YI & YI \\
\hline Baseline controls & Yes & Yes & Yes & Yes & Yes & Yes \\
\hline Pseudo-R2 & 0.162 & 0.165 & 0.163 & 0.152 & 0.147 & 0.168 \\
\hline Obs & 1,568 & 1,568 & 1,568 & 1,568 & 1,568 & 1,568 \\
\hline \multicolumn{7}{|c|}{ Panel E: institutional ownership characteristics and SEO issuance choice decisions } \\
\hline & \multicolumn{6}{|c|}{ Accelerated SEOs vs. Firm Commitment SEOs } \\
\hline Variables & (1) & (2) & (3) & (4) & (5) & (6) \\
\hline MA & & $\begin{array}{c}1.051 \\
(2.35)^{* * *}\end{array}$ & $\begin{array}{c}1.339 \\
(3.04)^{* * *}\end{array}$ & $\begin{array}{c}1.338 \\
(3.05)^{* * *}\end{array}$ & $\begin{array}{c}1.572 \\
(3.65)^{* * * *}\end{array}$ & $\begin{array}{c}1.048 \\
(2.34)^{* *}\end{array}$ \\
\hline INSDED & -0.974 & -0.944 & -0.858 & -0.578 & -0.412 & -1.029 \\
\hline & $(-1.27)$ & $(-1.25)$ & $(-1.17)$ & $(-0.81)$ & $(-0.58)$ & $(-1.36)$ \\
\hline INSTRA & -0.969 & -0.749 & -1.204 & -0.428 & -0.293 & -1.008 \\
\hline & $(-1.30)$ & $(-1.05)$ & $(-1.62)$ & $(-0.61)$ & $(-0.43)$ & $(-1.34)$ \\
\hline INSACTIVE & 0.002 & 0.001 & 0.000 & 0.001 & 0.001 & 0.001 \\
\hline & $(-1.70)^{*}$ & $(-1.65)^{*}$ & $(-0.02)$ & $(0.45)$ & $(0.62)$ & $(-1.26)$ \\
\hline SIZE & 0.287 & 0.348 & & & & 0.243 \\
\hline & $(2.88)^{* * *}$ & $(4.93)^{* * *}$ & & & & $(2.42)^{* *}$ \\
\hline LIQUID & -0.170 & & -0.457 & & & -0.194 \\
\hline & $(-1.16)$ & & $(-4.43)^{* * *}$ & & & $(-1.32)$ \\
\hline IDYRISK & -5.482 & & & -16.816 & & -3.210 \\
\hline & $(-0.86)$ & & & $(-2.49) * *$ & & $(-0.53)$ \\
\hline OРТОTА & 0.017 & & & & -0.224 & 0.002 \\
\hline & $(0.15)$ & & & & $(-0.93)$ & $(0.02)$ \\
\hline
\end{tabular}




\begin{tabular}{lcccccc}
\hline Fixed effects & YI & YI & YI & YI & YI & YI \\
Baseline controls & Yes & Yes & Yes & Yes & Yes & Yes \\
Pseudo- $R^{2}$ & 0.165 & 0.168 & 0.164 & 0.153 & 0.148 & 0.170 \\
Obs & 1,568 & 1,568 & 1,568 & 1,568 & 1,568 & 1,568 \\
\hline
\end{tabular}

